\title{
Rationalizing the Use of Water of Salinity Hazards for Irrigating Maize Grown in a Saline Sodic Soil
}

\author{
I. M. Farid", M.H.H. Abbas* and E. Fawzy ${ }^{*}$,** \\ "Soil and Water Department, Faculty of Agriculture, Benha \\ University, Benha and ${ }^{* *}$ General Department Irrigation Advisory \\ Services (GDIAS), Fayoum, Egypt.
}

\begin{abstract}
SOILS of Fayoum depression are mostly salt affected and usually $\checkmark$ irrigated with water of EC around $1.2 \pm 0.2 \mathrm{dS} \mathrm{m} \mathrm{m}^{-1}$. The current research was conducted to investigate the effects of gypsum, organic manure and humic acid applied to a saline sodic clay soil (EC $5.7 \pm 0.1$ ) singly or in combinations under two irrigation systems (furrow and drip systems) at two levels of irrigation (100\% of the water requirements (WR) and $75 \%$ of WR) on water saving in relation to maize productivity. The results indicated that amendments significantly increased grain yield; more upon using each singly than in combination. Increases were more pronounced with increasing the amount of irrigation water from $75 \%$ of the WR to $100 \%$ of WR. Grain yield was significantly higher in the second growing season than the first one which means a successful sustaining production of maize in the area of study. Protein content in grains ranged from 144.2 to 163.7 $\mathrm{g} \mathrm{kg}^{-1}$ which is higher than the protein content of the maize imported by Egypt from other countries. Virtual water values (VWV) ranged between 0.60 to $0.89 \mathrm{~m}^{3} \mathrm{~kg}^{-1}$ grains under drip system which was superior in the efficiency of using water for producing crop yield than values of 1.00 to $1.52 \mathrm{~m}^{3} \mathrm{~kg}^{-1}$ under the furrow system.
\end{abstract}

Keywords: Maize, Saline sodic soil, Gypsum, humic acid, Organic manure, Virtual water

River Nile is the main source of irrigation water in Egypt (Leger, 2004 and ElGammal, 2012) however, its amounts has become insufficient (Rijsberman, 2006) and the Egyptian government has moved towards integrated management of drainage water to increase the budget of water supply (Abdel-Kader and AbdelRassoul, 2010). Most soils of Fayoum depression is salt affected located in the western desert of Egypt (Abdel Aal and Ibrahim, 2013) and uses water of salinity hazards mixed with Nile water for crop irrigation (Mustafa et al., 2013). Drainage water of the agricultural drains goes mainly to Qarun lake which is located at about $43 \mathrm{~m}$ below sea level (Veer et al., 1993). There is no natural outlet for the lake and water loss from the lake takes place only through evaporation (Wolters et al., 1989). Thus, Fayoum is considered a closed drainage system (AboulFotouh et al., 2008). Accordingly, efficient management of low quality water to be used for irrigating such soils is vital.

Corresponding author: mohamed.abbas@fagr.bu.edu.eg 
One of the important guidelines for deciding the policies of improving the water efficiency for irrigation is the term 'virtual water' (El-Sadek, 2010), which refers to the amount of water needed for producing one $\mathrm{kg}$ of crop yield (Wichelns, 2001). This concept is the key towards efficient management of the natural resources to create self-sufficiency and to ensure the most profitable use of the irrigation water (Renault, 2002). It is a parameter measuring the degree of water use efficiency; and it is used in different forms and with different names (Hsaiao et al., 2007). Drip system is an efficient irrigation system for increasing the virtual water used in growing plants (Tognetti et al., 2003), beside of its effectiveness via furrow system for managing low quality irrigation water (Bably and El-Hafez, 2013 and Mustafa et al., 2013).

Maize which is a moderately sensitive crop for salinity (Yin et al., 2004), it is important crop in human food and livestock feed (Shiferaw et al., 2011 and Wu \& Guclu, 2013), beside involving in many industrial products such as starch, oil and fuel (FAO, 1992). Egypt is the main importer of maize in the region of North Africa (FAO, 2003) where it imports about 5 million mega grams annually (USDA, 2013). Prices of maize grains and oils are going up due to the population growth worldwide and the bio-fuel demands (McMichael, 2009 and Wright \& Cafiero, 2011). Accordingly, increasing the production of maize is required to meet the overgrowing demands for food and also to decrease its imports. In this concern, some seed varieties of high productivity have been introduced in the Egyptian market as salt tolerant, i.e., three way cross hybrid 2030.

Soil amendments can be used successfully for amelioration of sodic soil (Mustafa et al., 2013). Gypsum is a readily available source of calcium which can substitute undesired $\mathrm{Na}^{+}$in soil (Qadir et al., 2007). This could improve the properties of the soil and increase its productivity (Rasouli et al., 2013). Organic amendments can mobilize $\mathrm{Ca}^{2+}$ in soil and neutralize the residual sodium carbonate in soil solutions as well as reduce soil pH and ESP of the soil (Choudhary et al., 2011). Organic amendments and gypsum can minimize the undesirable effects of the low quality waters used in irrigation on the chemical and physical properties of the soil (Jalali and Ranjbar, 2009). Humic acid can also form stable soil aggregates and improve the physical properties of the soil through adsorption onto clay particles by polyvalent cations (Bronick and Lal, 2005).

The current research aims at investigating the effects of gypsum, organic matter and humic acid as soil amendments on increasing the productivity of maize plants grown in the sodic soil of Fayoum depression under two irrigation systems (furrow and drip systems) and two levels of irrigation ( $100 \%$ of the water requirements (WR) and $75 \%$ of WR).

\section{Material and Methods}

Soils and irrigation waters of study

Surface soil samples $(0-30 \mathrm{~cm})$ were collected from the area of study prior to each growing season. The samples were air dried, sieved to pass through $2 \mathrm{~mm}$

Egypt. J. Soil Sci. 54, No. 2 (2014) 
sieve and analyzed for their physical and chemical properties according to the standard methods outlined by Page et al. (1982) and Klute (1986). Physical and chemical properties of the studied soils are shown in Table 1.

TABLE 1. Physical and chemical properties of the soil under study.

\begin{tabular}{|l|c|c|c|c|c|c|c|c|c|}
\hline Soil parameter & $\begin{array}{c}\text { Sand, } \\
\mathbf{\%}\end{array}$ & $\begin{array}{c}\text { Silt, } \\
\mathbf{\%}\end{array}$ & $\begin{array}{c}\text { Clay, } \\
\mathbf{\%}\end{array}$ & $\begin{array}{c}\text { Soil } \\
\text { texture }\end{array}$ & $\mathbf{p H}$ & $\begin{array}{c}\mathbf{E C ,} \\
\mathbf{d S ~ m}^{-1}\end{array}$ & $\begin{array}{c}\mathbf{O M}, \\
\mathbf{g ~ k g}^{-1}\end{array}$ & $\begin{array}{c}\mathbf{C a C O}_{\mathbf{3}}, \\
\mathbf{g ~ k g}^{-1}\end{array}$ & $\mathbf{E S P}$ \\
\hline Summer 2010 & 16.2 & 23.2 & 60.6 & Clay & 7.6 & 5.7 & 16.1 & 128.1 & 15.1 \\
\hline Summer 2011 & 14.6 & 28.3 & 57.1 & Clay & 8.0 & 5.8 & 11.1 & 129.9 & 14.8 \\
\hline
\end{tabular}

EC: soil paste extract; $\mathrm{pH}$ in soil: water suspension 1:2.5; ESP: exchangeable sodium percent .

Samples of irrigation water were collected from the irrigation canals prior to each growing season and analyzed for their chemical properties (Table 2).

TABLE 2. The chemical properties of the irrigation water.

\begin{tabular}{|l|c|c|c|}
\hline Growing season & EC $_{\text {dS } \mathbf{~ m}^{-1}}$ & $\mathbf{p H}$ & SAR \\
\hline Summer 2010 & 1.41 & 8.40 & 3.88 \\
\hline Summer 2011 & 1.21 & 8.30 & 3.24 \\
\hline
\end{tabular}

Maize seeds and soil amendments

The seeds of maize "Zea mays cv three way cross hybrid 2030" were obtained from Misr HyTech Int., Egypt. Gypsum amendment (80\%) was obtained from Abou-Zaebal Company for Fertilizers, Egypt. Humic acid (analytical grade, 99\%) was obtained from Alpha Chemika Company. Organic manure was collected from the wastes of the animals of the farm of study. Physical and chemical properties of the used organic amendment are shown in Table 3.

TABLE 3. Chemical and physical properties of the organic manure.

\begin{tabular}{|c|c|c|c|c|c|c|c|}
\hline Parameter & $\mathbf{p H}^{*}$ & $\begin{array}{c}\text { EC* } \\
\mathbf{d S ~ m}^{-1}\end{array}$ & $\begin{array}{c}\text { Organic-C } \\
\mathbf{g ~ k g}^{-1}\end{array}$ & $\begin{array}{c}\text { Total-N } \\
\mathbf{g ~ k g}^{-1}\end{array}$ & $\begin{array}{c}\text { Total-P } \\
\mathbf{g ~ k g}^{-1}\end{array}$ & $\begin{array}{c}\text { Total-K } \\
\mathbf{g ~ k g}^{-1}\end{array}$ & $\begin{array}{c}\text { Bulk } \\
\mathbf{d e n s i t y} \\
\mathbf{M g ~ m}^{-3}\end{array}$ \\
\hline Value & 7.56 & 2.89 & 551.0 & 10.0 & 9.1 & 19.7 & 698.5 \\
\hline
\end{tabular}

\section{The field experiment}

A field experiment was conducted in Monshaet Snoras village, Fayoum governorate during the two successive summer seasons (April- August) of 2010 and 2011 to investigate the effect of using the drip irrigation system via the common used furrow irrigation system on increasing the water use efficiencies and productivity of maize in the area of study. There were two different levels of irrigation, i.e., $100 \%$ of the water requirements (WR) and $75 \%$ of WR under two systems of irrigation (furrow vs. drip system). There were also six treatments of 
amendments as follows: (1) non amended, (2) organic manure (OM), (3) gypsum (GP), (4) humic acid (Hmc), (5) OM+GP mixture and (6) GP+Hmc mixture. This experiment was conducted in a split-split-plot design with the irrigation system as the main plots, the irrigation requirements as the sub-plots and the amendment treatments as the sub-sub-plot. The OM was applied at a rate of $24 \mathrm{Mg} \mathrm{ha}^{-1}$, GP was applied at a rate of $10 \mathrm{Mg} \mathrm{ha}^{-1}$, Hmc was applied at a rate of $14 \mathrm{~kg} \mathrm{ha}^{-1}$. The $\mathrm{OM}+\mathrm{GP}$ rate consisted of " $12 \mathrm{Mg}+5 \mathrm{Mg}$ " $\mathrm{ha}^{-1}$, while the $\mathrm{GP}+\mathrm{Hmc}$ rate consisted of " $5 \mathrm{Mg}+7 \mathrm{Mg}$ " $\mathrm{ha}^{-1}$. Treatments were executed in three replicates. The area of the experimental plot was $12.6 \mathrm{~m}^{2}$. Seeds of maize were sown and all the experimental plots received the recommended doses of NP fertilizers according to the recommendations of the Egyptian Ministry of Agriculture, i.e., $20 \mathrm{~kg} \mathrm{P}^{-1}$ (as Ca-super phosphate $65.5 \mathrm{~g} \mathrm{P} \mathrm{kg}^{-1}$ ) added with soil preparation and $80 \mathrm{~kg} \mathrm{~N}$ (as ammonium sulphate, $210 \mathrm{~g} \mathrm{~N} \mathrm{~kg}^{-1}$ ) applied at four equal doses during soil preparation, thinning, early silking and full silking. All the agricultural practices were done as recommended. At the physiological maturity, the kernels were collected and grains were separated from the kernels using a Sheller. The grain yield was recorded and the virtual water value "VWV" $\left(\mathrm{m}^{3} \mathrm{~kg}^{-1}\right)$ was calculated for each plot as the amount of the consumed water in $\mathrm{m}^{3}$ for the production of one $\mathrm{kg}$ of crops (Renault, 2002)

$$
\text { VWV }\left(\mathrm{m}^{3} \mathrm{~kg}^{-1}\right)=\frac{\text { Consumed water }\left(\mathrm{m}^{3}\right)}{\text { Yield }(\mathrm{kg})}
$$

The amounts of water required for irrigation (WR) were calculated on basis of the ordinary irrigation requirements of maize in non-saline soil plus $10 \%$ leaching requirements (LR). The amount of irrigation requirement under furrow (surface) irrigation system was considered $9500 \mathrm{~m}^{3} \mathrm{ha}^{-1}$ (Maatouk and El-Karamity, 2005). On this basis, the two levels of irrigation water used in the current study (including $10 \% \mathrm{LR}$ ) were $10480 \mathrm{~m}^{3} \mathrm{ha}^{-1}$ equivalent to $100 \%$ of WR and $7860 \mathrm{~m}^{3}$ $\mathrm{ha}^{-1}$ equivalent to $75 \%$ of WR. The flow of water in the irrigation canals was regulated during the field study by the flow meter (velocity-area method) as outlined by Michalski (2000) and Mustafa et al. (2013). Water was added in the form of 8 furrow irrigations. In case of drip irrigation, the ordinary irrigation requirements of maize was considered $5680 \mathrm{~m}^{3} \mathrm{ha}^{-1}$ according to Abd El-Hafez et al. (2001). Therefore, the two levels of irrigation water including $10 \% \mathrm{WR}$ used under drip irrigation for $100 \%$ WR was $6250 \mathrm{~m}^{3} \mathrm{ha}^{-1}$, while the corresponding one for the $75 \%$ WR was $4700 \mathrm{~m}^{3} \mathrm{ha}^{-1}$. The number of irrigations was 15 irrigations.

\section{Protein analysis in maize grains}

Samples of maize grains were oven-dried for $48 \mathrm{hr}$ at $70^{\circ} \mathrm{C}$ and ground. Portions of the dried plant samples, $0.2 \mathrm{~g}$ each were placed in digestive tubes together with a mixture of concentrated sulfuric $\left(\mathrm{H}_{2} \mathrm{SO}_{4}\right)$ acid and perchloric $\left(\mathrm{HClO}_{4}\right)$ acid at a ratio of 1:1 and left overnight, afterwards digested according to Ryan et al. (1996). Total $\mathrm{N}$ in the plant digest was determined using the Kjeldahl method and the crude protein content was calculated in maize grains by multiplying N\% with the factor of 6.25 (Idikut et al.,2009).

Egypt. J. Soil Sci. 54, No. 2 (2014) 


\section{Results and Discussion}

Grain yield as affected by type of the soil amendment system and level of irrigation water

Application of soil amendments increased significantly the yield of maize grains $(\mathrm{P}=0.005)$. Such increases were more significantly higher due to applications of OM, GP and Hmc singly rather than the mixed applications of "OM+GP" or "GP+Hmc" (Table 4). These results are in agreement with those obtained by Lui et al. (2010), Chivenge et al. (2011), Shafi et al. (2012) and Mustafa (2013) who found significant increases in the grain yield of maize with the application of organic manure. Abd Elrahman et al. (2012) reported significant increases in the productivity of grain yield with application of gypsum and that the combined application (organic matter +gypsum) treatment recorded higher significant increases in the grain yield than did the single amendments. However, Choudhary et al. (2011) found that the combined application of gypsum and organic manure caused no significant increases in the yields of rice and wheat crops over yields given by organic manure or gypsums alone.

Significant increases in grain yield were shown with increasing the amount of irrigation water from $75 \%$ of the WR to $100 \%$ of $\mathrm{WR}(\mathrm{P}<0.001)$. However, there was no significant effect due to system of irrigation on the grain yield $(\mathrm{P}=0.110)$. Berrade and Halvorson (2012) found no significant differences in maize yield between drip and furrow irrigation; however drip irrigation used $42 \%$ less water. The grain yields were significantly higher in the second growing season than the first one $(\mathrm{P}=0.010)$. This guarantee sustaining production of maize in the area of study.

The obtained yield (between 6.467 to $8.933 \mathrm{Mg} \mathrm{ha}^{-1}$ ) was almost near the average grain yields recorded in other countries, i.e., 3.40 to $7.66 \mathrm{Mg} \mathrm{ha}^{-1}$ in China (Liu et al., 2010), 4.890 and $9.863 \mathrm{Mg} \mathrm{ha}^{-1}$ in Iran (Lashkari et al., 2012), around $9 \mathrm{Mg} \mathrm{ha}^{-1}$ in France and around $8.8 \mathrm{Mg} \mathrm{ha}^{-1}$ in Italy (USDA, 2013).

Protein content in maize grains as affected by type of the soil amendment, system and level of irrigation water

Protein content in maize grains increased significantly under drip irrigation system than under furrow irrigation system $(\mathrm{P}<0.001)$. The increases were more obvious with increasing the amount of irrigation water from $75 \%$ to $100 \%$ of WR $(\mathrm{P}<0.001)$. Also, the applied soil amendments caused further significant increases in the grain yield $(\mathrm{P}<0.001)$, especially "OM+GP" (Table 5). Protein content ranged from 144.2 to $163.7 \mathrm{~g} \mathrm{~kg}^{-1}$. These values were greater than those recorded in maize grains of the high-oil inbred line, By804, and the regular inbred line, B73 in China (Guo et al., 2013) which ranged between 86.7 and $121.9 \mathrm{~g} \mathrm{~kg}^{-1}$, respectively. They also exceeded values in Turky, which varied between 89.1 $116.5 \mathrm{~g} \mathrm{~kg}^{-1}$ (Idikut et al., 2009). Thus the grains obtained in the current study were of higher protein content than those of the maize grains imported from China and Turkey. Even between the main exporters of maize grains worldwide which are Argentina and Brazil (USDA, 2013), protein content in grown therein maize is higher, where the protein content ranged from 88.0 to $119.0 \mathrm{~g} \mathrm{~kg}^{-1}$ in Argentine maize race (Robutti et al. ,2000) and from 105.1 to $115.8 \mathrm{~g} \mathrm{~kg}^{-1}$ in the Brazilian maize (Mittelmann et al., 2011). 
TABLE 4. Maize grain yield $\left(\mathrm{kg} \mathrm{ha}^{-1}\right)$ as affected by the type of soil amendment, system and level of irrigation water .

\begin{tabular}{|c|c|c|c|c|c|c|}
\hline \multirow[t]{2}{*}{ Treatment } & \multirow[t]{2}{*}{ Season } & \multicolumn{2}{|c|}{ Furrow irrigation } & \multicolumn{2}{|c|}{ Drip irrigation } & \multirow[b]{2}{*}{$\begin{array}{r}\text { Grand } \\
\text { mean } \\
\end{array}$} \\
\hline & & $\begin{array}{l}75 \% \\
\text { WR } \\
\end{array}$ & $\begin{array}{l}100 \% \\
\text { WR }\end{array}$ & $\begin{array}{l}75 \% \\
\text { WR } \\
\end{array}$ & $\begin{array}{l}100 \% \\
\text { WR } \\
\end{array}$ & \\
\hline \multirow[t]{3}{*}{ Non-amended } & $1^{s t}$ & 6,467 & 6,633 & 6,633 & 7,100 & 6,467 \\
\hline & $2^{\text {nd }}$ & 6,733 & 6,833 & 6,900 & 7,467 & 6,733 \\
\hline & mean & 6,600 & 6,733 & 6,767 & 7,283 & 6,600 \\
\hline \multirow{3}{*}{$\begin{array}{l}\text { Organic manure } \\
(\mathrm{OM})\end{array}$} & $1^{s t}$ & 6,933 & 8,067 & 7,100 & 8,433 & 6,933 \\
\hline & $2^{n d}$ & 7,100 & 8,167 & 7,200 & 8,933 & 7,100 \\
\hline & mean & 7,017 & 8,117 & 7,150 & 8,683 & 7,017 \\
\hline \multirow[t]{3}{*}{ Gypsum (GP) } & $1^{s t}$ & 6,800 & 8,033 & 7,000 & 8,367 & 6,800 \\
\hline & $2^{\text {nd }}$ & 6,967 & 8,300 & 7,033 & 8,833 & 6,967 \\
\hline & mean & 6,883 & 8,167 & 7,017 & 8,600 & 6,883 \\
\hline \multirow[t]{3}{*}{ Humic acid (Hmc) } & $1^{s t}$ & 6,733 & 8,000 & 7,000 & 8,100 & 6,733 \\
\hline & $2^{n d}$ & 7,200 & 8,067 & 7,002 & 8,533 & 7,200 \\
\hline & mean & 6,967 & 8,033 & 7,001 & 8,317 & 6,967 \\
\hline \multirow[t]{3}{*}{ “OM +GP” } & $1^{s t}$ & 6,733 & 8,001 & 6,967 & 7,967 & 6,733 \\
\hline & $2^{\text {nd }}$ & 6,833 & 8,000 & 6,965 & 8,367 & 6,833 \\
\hline & mean & 6,783 & 8,001 & 6,966 & 8,167 & 6,783 \\
\hline \multirow[t]{3}{*}{ "GP+Hmc" } & $1^{s t}$ & 6,700 & 8,400 & 6,900 & 7,633 & 6,700 \\
\hline & $2^{\text {nd }}$ & 6,800 & 8,402 & 6,933 & 7,867 & 6,800 \\
\hline & mean & 6,750 &, 8401 & 6,917 & 7,750 & 6,750 \\
\hline \multicolumn{7}{|c|}{ Main effects of the system and level of irrigation water } \\
\hline \multirow{5}{*}{$\begin{array}{l}\text { Furrow system } \\
\text { Drip system } \\
\text { Mean }\end{array}$} & & $75 \%$ & $100 \%$ & & & \\
\hline & & WR & WR & Mean & & \\
\hline & & 6,833 & 7,910 & 7,371 & & \\
\hline & & 6,969 & 8,133 & 7,552 & & \\
\hline & & 6,902 & 8,021 & & & \\
\hline
\end{tabular}

LSD(0.05): season (885), irr level (885), amend (511), season $\times$ WR level (1,257), season $\times$ amend (1,032), WR levelx amend(1,032), season $\times$ amendx irr level $(1,361) .1^{\text {st }} \& 2^{\text {nd }}$ denote seasons .

Egypt. J. Soil Sci. 54, No. 2 (2014) 
TABLE 5. Protein content in grains $\left(\mathrm{g} \mathrm{kg}^{-1}\right)$ as affected by type of the soil amendment, system and level of irrigation water .

\begin{tabular}{|c|c|c|c|c|c|c|}
\hline \multirow[t]{2}{*}{ Treatment } & \multirow[t]{2}{*}{ Season } & \multicolumn{2}{|c|}{ Furrow irrigation } & \multicolumn{2}{|c|}{ Drip irrigation } & \multirow{2}{*}{$\begin{array}{l}\text { Grand } \\
\text { mean }\end{array}$} \\
\hline & & $\begin{array}{l}75 \% \\
\text { WR }\end{array}$ & $\begin{array}{l}100 \% \\
\text { WR }\end{array}$ & $\begin{array}{l}75 \% \\
\text { WR }\end{array}$ & $\begin{array}{l}100 \% \\
\text { WR }\end{array}$ & \\
\hline \multirow[t]{2}{*}{ Non-amended } & $1^{s t}$ & 141.3 & 141.6 & 142.1 & 143.2 & 142.0 \\
\hline & $\begin{array}{l}2^{\text {nd }} \\
\text { mean }\end{array}$ & $\begin{array}{l}141.2 \\
141.2\end{array}$ & $\begin{array}{l}141.4 \\
141.5\end{array}$ & $\begin{array}{l}141.8 \\
141.9\end{array}$ & $\begin{array}{l}142.5 \\
142.9\end{array}$ & $\begin{array}{l}141.7 \\
141.9\end{array}$ \\
\hline \multirow{3}{*}{$\begin{array}{l}\text { Organic manure } \\
\text { (OM) }\end{array}$} & $1^{s t}$ & 144.3 & 152.9 & 151.6 & 163.7 & 153.1 \\
\hline & $2^{\text {nd }}$ & 144.0 & 152.7 & 151.5 & 162.1 & 152.7 \\
\hline & mean & 144.2 & 152.8 & 151.5 & 162.9 & 152.9 \\
\hline \multirow[t]{3}{*}{ Gypsum (GP) } & $1^{s t}$ & 143.9 & 152.4 & 151.2 & 162.6 & 152.5 \\
\hline & $2^{\text {nd }}$ & 143.3 & 152.2 & 151.1 & 160.3 & 151.7 \\
\hline & mean & 143.6 & 152.3 & 151.1 & 161.5 & 152.1 \\
\hline \multirow[t]{2}{*}{$\begin{array}{l}\text { Humic acid } \\
(\mathrm{Hmc})\end{array}$} & $1^{\text {st }} 2^{\text {nd }}$ & $\begin{array}{l}141.5 \\
141.8\end{array}$ & $\begin{array}{l}151.1 \\
150.7\end{array}$ & $\begin{array}{l}150.5 \\
150.4\end{array}$ & $\begin{array}{l}158.5 \\
157.6\end{array}$ & $\begin{array}{l}150.4 \\
150.1\end{array}$ \\
\hline & mean & 141.6 & 150.9 & 150.4 & 158.0 & 150.3 \\
\hline \multirow[t]{2}{*}{ "OM +GP" } & $\begin{array}{l}1^{s t} \\
2^{n d}\end{array}$ & $\begin{array}{l}141.6 \\
141.8\end{array}$ & $\begin{array}{l}151.2 \\
151.0\end{array}$ & $\begin{array}{l}150.7 \\
150.4\end{array}$ & $\begin{array}{l}158.9 \\
157.4\end{array}$ & $\begin{array}{l}150.6 \\
1501\end{array}$ \\
\hline & mean & 141.7 & 151.1 & 150.6 & 158.1 & 150.4 \\
\hline \multirow[t]{3}{*}{ "GP+Hmc" } & $1^{s t}$ & 141.5 & 151.1 & 151.0 & 158.6 & 150.6 \\
\hline & $2^{n d}$ & 141.3 & 151.1 & 150.7 & 156.6 & 149.9 \\
\hline & mean & 141.4 & 151.1 & 150.8 & 157.6 & 150.2 \\
\hline \multicolumn{7}{|c|}{ Main effects of the system and level of irrigation water } \\
\hline & & $\begin{array}{l}75 \% \\
\text { WR }\end{array}$ & $100 \% \mathrm{WI}$ & Mean & & \\
\hline Furrow system & & 142.3 & 149.4 & 145.8 & & \\
\hline $\begin{array}{l}\text { Drip system } \\
\text { Mean }\end{array}$ & & $\begin{array}{l}150.0 \\
146.2\end{array}$ & $\begin{array}{l}156.8 \\
153.2\end{array}$ & 153.4 & & \\
\hline
\end{tabular}

LSD(0.05): season (2.5), irr sys (2.5), irr level (2.5), amend (1.5), amend× irr sys (2.9), amend $\times$ irr lev (2.9), irr sys $\times$ irr level $\times$ amend(1.6). $1^{\text {st }} \& 2^{\text {nd }}$ denote seasons .

Virtual water value as affected by type of the soil amendment, system and level of irrigation water

The virtual water values (VWV) were significantly lower with the application of soil amendments $(\mathrm{P}<0.001)$, especially under the drip irrigation system rather than the furrow system (Table 6). These values ranged from 0.60 to $0.89 \mathrm{~m}^{3} \mathrm{~kg}^{-1}$ grains under drip irrigation corresponding to 1.00 to $1.52 \mathrm{~m}^{3} \mathrm{~kg}^{-1}$ grains under furrow irrigation. This was more pronounced with the application of $75 \%$ of WR than $100 \%$ of WR 
$(\mathrm{P}<0.001)$. Irrigation using drip system was of lower VWV values than the furrow system $(\mathrm{P}<0.001)$. There was no significant difference between the two growing seasons $(\mathrm{P}=0.050)$. Sheng et al. (2009) stated that soil salinity is one of the main abiotic factors limiting crop production and the system of irrigation which attains greater water use efficiency guarantees low salt inputs for the sodic soil of study . Renault (2002) reported that VWV for irrigated maize ranged between 0.7 to $1.9 \mathrm{~kg}$ $\mathrm{m}^{3}$ which were rather comparable with the values obtained herein in the current study. Thus, maize under drip irrigation systems using water of medium salinity hazards could be of a positive effect. This indicates that drip irrigation system would be preferred in Fayoum region because of the shortage in the amounts of irrigation water.

TABLE 6. Virtual water value "VWV" $\left(\mathrm{m}^{3} \mathrm{~kg}^{-1}\right)$ as affected by the application of soil amendment, system and level of irrigation water.

\begin{tabular}{|c|c|c|c|c|c|c|}
\hline \multirow{3}{*}{ Zero amendment } & \multirow[b]{3}{*}{$1^{s t}$} & \multicolumn{2}{|c|}{ Furrow irrigation } & \multirow[b]{2}{*}{$75 \%$} & Drip irrigation & \multirow{2}{*}{$\begin{array}{r}\text { Grand } \\
\text { mean }\end{array}$} \\
\hline & & $\begin{array}{l}75 \% \\
\text { WR }\end{array}$ & $\begin{array}{r}100 \% \\
\text { WR }\end{array}$ & & WR & \\
\hline & & 1.23 & 1.25 & 0.69 & 0.82 & 1.23 \\
\hline & $2^{\text {nd }}$ & 1.16 & 1.54 & 0.68 & 0.84 & 1.16 \\
\hline & mean & 1.20 & 1.37 & 0.68 & 0.83 & 1.20 \\
\hline Organic manure & $1^{s t}$ & 1.27 & 1.33 & 0.68 & 0.79 & 1.27 \\
\hline$(\mathrm{OM})$ & $2^{\text {nd }}$ & 1.11 & 1.28 & 0.65 & 0.70 & 1.11 \\
\hline & mean & 1.18 & 1.30 & 0.67 & 0.74 & 1.18 \\
\hline Gypsum (GP) & $1^{s t}$ & 1.04 & 1.52 & 0.61 & 0.89 & 1.04 \\
\hline & $2^{\text {nd }}$ & 1.12 & 1.27 & 0.67 & 0.71 & 1.12 \\
\hline & mean & 1.09 & 1.37 & 0.64 & 0.79 & 1.09 \\
\hline Humic acid & $1^{s t}$ & 0.92 & 1.52 & 0.60 & 0.89 & 0.92 \\
\hline$(\mathrm{Hmc})$ & $2^{\text {nd }}$ & 1.09 & 1.30 & 0.67 & 0.73 & 1.09 \\
\hline & mean & 1.00 & 1.39 & 0.64 & 0.81 & 1.00 \\
\hline "OM +GP" & $1^{s t}$ & 1.14 & 1.39 & 0.68 & 0.81 & 1.14 \\
\hline & $2^{\text {nd }}$ & 1.15 & 1.32 & 0.68 & 0.75 & 1.15 \\
\hline & mean & 1.14 & 1.35 & 0.68 & 0.78 & 1.14 \\
\hline "GP+Hmc" & $1^{s t}$ & 1.14 & 1.33 & 0.67 & 0.78 & 1.14 \\
\hline & $2^{\text {nd }}$ & 1.15 & 1.25 & 0.68 & 0.79 & 1.15 \\
\hline & mean & 1.15 & 1.28 & 0.68 & 0.79 & 1.15 \\
\hline \multicolumn{7}{|c|}{ Main effects of the system and level of irrigation water } \\
\hline \multirow{5}{*}{$\begin{array}{l}\text { Furrow system } \\
\text { Drip system } \\
\text { Mean }\end{array}$} & & $75 \%$ & $100 \% \mathrm{WR}$ & Mean & & \\
\hline & & WR & & & & \\
\hline & & 1.12 & 1.35 & 1.22 & & \\
\hline & & 0.66 & 0.79 & 0.72 & & \\
\hline & & 0.83 & 0.99 & & & \\
\hline
\end{tabular}

LSD(0.05): season (0.12), irr sys (0.12), irr level (0.12), amend (0.07), season $\times$ WR level $(0.17)$, season $\times$ amend (0.14), irr sys $\times$ irr level $(0.17)$, irr level $\times$ amend $(0.14)$, season $\times$ amend $\times$ irr level $(0.19)$, season $\times$ amend $\times$ irr level $(0.19)$ season $\times$ irr sys $\times$ irr level $\times$ amend $(0.22) .1^{\text {st }} \& 2^{\text {nd }}$ denote seasons . 


\section{Conclusion}

The Egyptian government must take drastic steps towards increasing the production of maize grains in Egypt as a strategic crop for human food and animal feeding. These steps may include (1) encouraging farmers to switch their irrigation system from the furrow to the drip system (2) providing guidelines on the importance of the application of soil amendments (3) determining fair rates for the price of maize grains, beside of providing a real subsiding to the production requirements of maize.

Acknowledgement: The authors would like to express their deep thanks to Prof. Dr. Hassan H. Ramadan and Prof. Dr. Aly A. Abdel Salam Soils Department, Benha University, Egypt for their help with this study.

\section{References}

Abd El-Hafez, S.A., El-Sabbagh, A.A., El-Bably , A.Z. and Abo-Ahmed, E.I. (2001) Response of maize crop to drip irrigation in clay soils. Alex. J. Agric. Res. 46:153-159.

Abd Elrahman, S.H., Mostafa, M.A.M., Taha, T.A., Elsharawy, M.A.O. and Eid, M.A. (2012) Effect of different amendments on soil chemical characteristics, grain yield and elemental content of wheat plants grown on salt-affected soil irrigated with low quality water. Annals of Agricultural Sciences 57:175-182.

Abdel-Kader, A.M. and Abdel-Rassoul, S.M. ( 2010) Prospects of water conservation in Egypt (special reference to wastewater reuse). Fourteenth International Water Technology Conference, IWTC 14, Cairo, Egypt.March 21-23, pp. 519-526.

Abdel Aal, T. and Ibrahim, A.M. (2013) Studies on the micromorphology of saltaffected soils from El-Fayoum Depression, Egypt. In: "Developments in Soil Classification, Land Use Planning and Policy Implications", S.A. Shahid, F.K. Taha and M.A. Abdelfattah (Ed.), pp. 373-392, Springer Netherlands.

Aboul-Fotouh, N., Abdin, A.E. and Sedky, S. (2008) Assessment of grass roots irrigation water conflicts through governorates' profile. Options Mediterraneennes, 83 Water Culture and Water Coflict in the Mediterranean Area, pp. 185-196.

Bably, A.Z.E. and El-Hafez, S.A.A. (2013) Sustainable development and management policies for soil and water conservation in Egypt. In: "Developments in Soil Classification, Land Use Planning and Policy Implications", S.A. Shahid, F.K. Taha and M.A. Abdelfattah (Ed.), pp. 633-647, Springer Netherlands.

Berrada, A.F. and Halvorson, A.D. (2012) Manure and nitrogen fertilizer effects on corn productivity and soil fertility under drip and furrow irrigation. Arch. Agron. Soil Sci 58: $1329-1347$.

Bronick, C.J. and Lal, R. (2005) Soil structure and management: a review. Geoderma 124: 3-22. 
Chivenge, P., Vanlauwe, B. and Six, J. (2011) Does the combined application of organic and mineral nutrient sources influence maize productivity? A meta-analysis. Plant Soil 342: $1-30$.

Choudhary, O.P., Ghuman, B.S., Bijay, S., Thuy, N. and Buresh, R.J. (2011) Effects of long-term use of sodic water irrigation, amendments and crop residues on soil properties and crop yields in rice-wheat cropping system in a calcareous soil. Field Crop Res. 121: 363-372.

El-Gammal, H.A.A. (2012) Water quality protection in rular areas of Egypt. International Water Technology Journal 1: 230-238.

El-Sadek, A. (2010) Virtual water trade as a solution for water scarcity in Egypt. Water Resour. Manag. 24: 2437-2448.

FAO (1992) Maize in human nutrition. Food and Agriculture Organization of the United Nations, No. 25, Rome, Italy.

FAO (2003) Financing normal levels of commercial basic foodstuffs in the context of the Marrakesh decision on least-developed and net food-importing developing countries. Food and Agriculture Organization of the united nations, Rome, Italy.

Guo, Y., Xiaohong, Y., Chander, S., Yan, J., Zhang, J., Song, T. and Li, J. (2013) Identification of unconditional and conditional QTL for oil, protein and starch content in maize. The Crop Journal.

Hsaiao, T.C., Steduto, P. and Fereres, E. (2007) A systematic and quantitative approach to improve water use efficiency in agriculture. Irrig. Sci. 25: 209-231 .

Idikut, L., Atalay, A.I., Kara, S.N. and Kamalak, A. (2009) Effect of hybrid on starch, protein and yields of maize grain. J. Anim. Vet. Adv. 8: 1945-1947.

Jalali, M. and Ranjbar, F. (2009) Effects of sodic water on soil sodicity and nutrient leaching in poultry and sheep manure amended soils. Geoderma 153: 194-204.

Klute, A. (1986) "Part 1. Physical and Mineralogical Methods", ASA-SSSA-Agronomy, Madison, Wisconsin USA.

Lashkari, A., Alizadeh, A., Rezaei, E. and Bannayan, M. (2012) Mitigation of climate change impacts on maize productivity in northeast of Iran: a simulation study. Mitig. Adapt Strateg Glob Change 17: 1-16.

Leger, F. (2004) Private sector participation in the water and waste water sectors in Egypt: constraints and opportunities. J. En. Nat. Res. L. 22: 42-50.

Liu, E., Yan, C., Mei, X., He, W., Bing, S.H., Ding, L., Liu, Q., Liu, S. and Fan, T. (2010) Long-term effect of chemical fertilizer, straw, and manure on soil chemical and biological properties in northwest China. Geoderma 158: 173-180.

Maatouk, M.A. and El-Karamity, A.E. (2005) "Crop Irrigation and Water Requirements" (In arabic). The Anglo Egyptian Bookshop, Cairo, Egypt.

Egypt. J. Soil Sci. 54, No. 2 (2014) 
McMichael, P. (2009) A food regime analysis of the 'world food crisis. Agric. Hum. Values 26: 281-295.

Michalski, A. (2000) Flow measurements in open irrigation channels. IEEE Instru. Meas. Mag. 3: 12-16.

Mittelmann, A., Miranda, J.B.D., Filho, L.L., Nass, G.J.M., Lima, M.D., Hara-Klein, C. and Silva, R.M.D. (2011) Quantitative variation for grain quality in Brazilian maize populations. Sci. Agric. 68: 50-56.

Mustafa, E.F., Farid, I.M. and Abbas, M.H.H. (2013) Yield economical return and ameliorating effect of sugar beet grown in sodic soil irrigated with low quality water. Energy Ecology Economy 2: 115-120.

Page, A.L., Miller, R.H. and Keeney, D.R. (1982) "Methods of Soil Analysis Part II Chemical and Microbiological Properties", ASA-SSSA, Agronomy, Madison, USA.

Qadir, M., Oster, J.D., Schubert, S., Noble, A.D. and Sahrawat, K.L. (2007) Phytoremediation of sodic and saline - sodic soils. In: "Advances In Agronomy", L.S. Donald (Ed.), pp. 197-247. Academic Press.

Rasouli, F., Kiani, P.A. and Karimian, N. (2013) Wheat yield and physico-chemical properties of a sodic soil from semi-arid area of Iran as affected by applied gypsum. Geoderma 193-194, 246-255.

Renault, D. (2002) Values of virtual water in food: principles and virtues. Workshop on Virtual Water Trade, December 12-13, Delft, The Netherlands.

Rijsberman, F.R. (2006) Water scarcity: Fact or fiction? Agr. Water Manage. 80: 5-22.

Robutti, J., Borras, F., Ferrer, M., Percibaldi, M. and Knutson, C.A. (2000) Evaluation of quality factors in Argentine maize races. Cereal Chem. 77: 24-26.

Ryan, J., Garabet, S., Harmsen, K. and Rashid, A. (1996) A soil and plant analysis manuel adapted for the West Asia and North Africa region. ICARDA, Aleppo, Syria.

Shafi, M., Shah, A., Bakht, J., Shah, M. and Mohammad, W. (2012) Integrated effect of inorganic and organic nitrogen sources on soil fertility and productivity of maize. J. Plant Nutr. 35: 524-537.

Sheng, M., Tang, M., Chen, H., Yang, B., Zhang, F. and Huang, Y. (2009) Influence of arbuscular mycorrhizae on the root system of maize plants under salt stress. Can. J. Microbiol. 55: 879-886.

Shiferaw, B., Prasanna, B., Hellin, J. and Bänziger, M. (2011) Crops that feed the world 6. Past successes and future challenges to the role played by maize in global food security. Food Sci. 3: 307-327.

Tognetti, R., Palladino, M., Minnocci, A., Delfine, S. and Alvino, A. (2003) The response of sugar beet to drip and low-pressure sprinkler irrigation in southern Italy. Agr. Water. Manage. 60: 135-155. 
USAID (2013) Price watch January 2013 prices. Famine Early Warning Systems Network (FEWS NET). Accessed: 28 February.

USDA (2013) World Corn Trade Foreign Agricultural Service. U.S. Department of Agriculture (USDA). Accessed: 9 February.

Veer, M., Wormgoor, J. A., Rizq, R. and Wolters, W. (1993) Water management in tertiary units in the Fayoum, Egypt. Irrig. Drainage Syst. 7: 69-82.

Wichelns, D. (2001) The role of 'virtual water' in efforts to achieve food security and other national goals, with an example from Egypt. Agr. Water Manage. 49: 131-151.

Wolters, W., Ghobrial, N., Leeuwen, H.M. and Bos, M.G. (1989) Managing the water balance of The Fayoum Depression, Egypt. Irrig. Drainage. Syst. 3: 103-123.

Wright, B. and Cafiero, C. (2011) Grain reserves and food security in the Middle East and North Africa. Food Sci. 3: 61-76.

Wu, F. and Guclu, H. ( 2013) Global Maize Trade and Food Security: Implications from a Social Network Model. Risk Anal.

Yin, X.Y., Yang, A.F., Zhang, K.W. and Zhang, J.R. (2004) Production and analysis of transgenic maize with improved salt tolerance by the introduction of AtNHX1 gene. Acta Bot. Sin. 46: 854-861.

(Received 3/10/2013;

accepted 30/11/2013) 


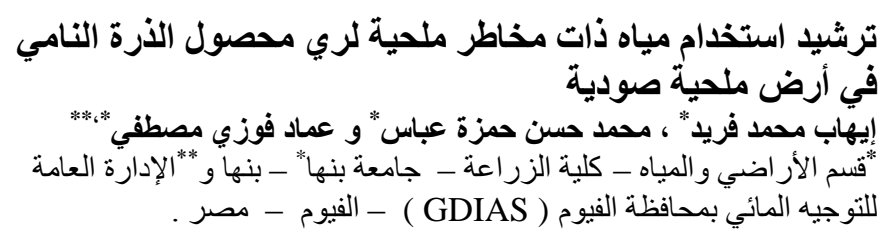

بعتبر معظم أراضي منخفض الفيوم متأثرة بالأملاح والتي تروي بمياه ذات

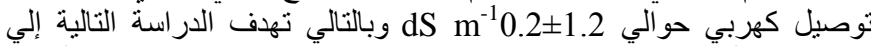

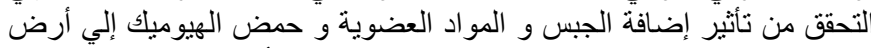

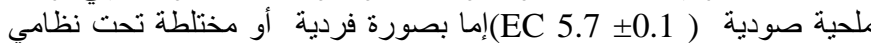

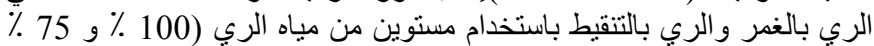

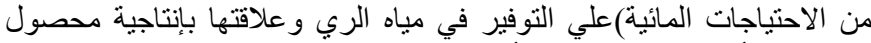

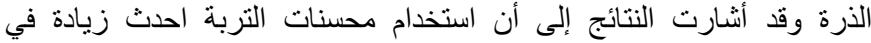

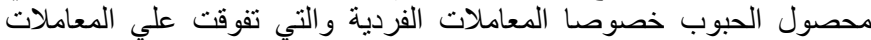

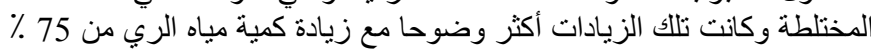

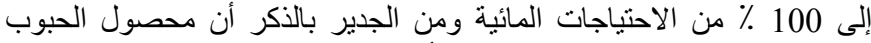

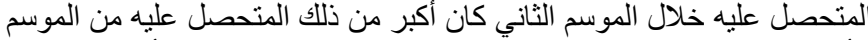

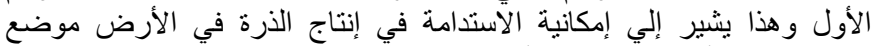

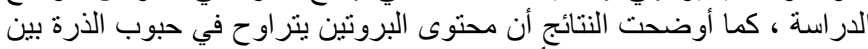

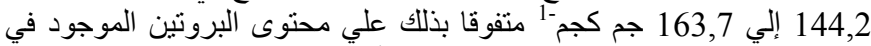

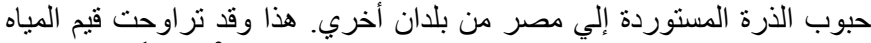

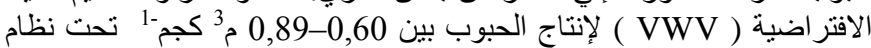

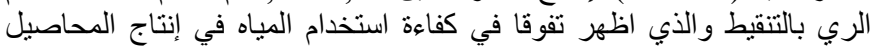

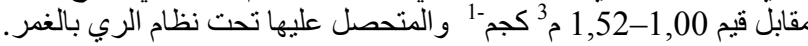

